\title{
Nutritional status of Terena indian children from Mato Grosso do Sul, Brazil: follow up of weight and height and current prevalence of anemia
}

\author{
Mauro Batista Morais, ${ }^{1}$ Gildney Maria dos Santos Alves, ${ }^{2}$ Ulysses Fagundes-Neto ${ }^{3}$
}

\begin{abstract}
Objective: This study of Terena Indian children less than 10 years old was undertaken in order to compare weight and height in 1995 and 2002 and to evaluate anemia prevalence in 2002.

Methods: This was a cross-sectional study of the Limão Verde and Córrego Seco tribes, located in Aquidauana, Mato Gosso do Sul, Brazil. The study enrolled all 253 children who were less than 10 years old in 1995 and 244 who were under 10 in 2002. Their nutritional status was evaluated comparing weight and height with the NCHS (National Center for Health Statistics) reference values (Epi-Info version 6.2). Hemoglobin was assayed using a portable photometer.

Results: The percentages of children with weight for age deficit ( $z$ score $<-2$ standard deviations) were 4 and $2.9 \%$ in 1995 and 2002 respectively. Percentages of weight for height deficits were 3.6 and $0.8 \%$ respectively. Percentages of height for age deficits were 15 and $11.1 \%$ respectively. The median z scores for weight, age and weight, and height showed a statistically significant increase during the period between 1995 and 2002 in infants. Between 24 and 60 months, there were increments in median $z$ scores for weight for age and height for age. There was no statistically significant decrease in any of the anthropometric indicators, with reference to $z$ scores. The prevalence rates of anemia were $86.1 \%$ for infants 6 to 24 months old $(n=43), 50.8 \%$ for those 24 to 60 months $(n=65)$ and $40.7 \%$ for children aged 60 to 120 months $(n=59)$.
\end{abstract}

Conclusion: Weight and height both increased during period from 1995 to 2002 . Anemia was highly prevalent, calling for immediate corrective measures.

J Pediatr (Rio J). 2005;81(5):383-9: Child Nutrition, anthropometry, anemia, South American Indians.

\section{Introduction}

Nutritional status is one of the principal indicators of the condition of a population's health, and anthropometry, due to its practicality and low cost, is used in the greater part of studies undertaken within the community, 1,2 including those of indigenous groups. In an earlier study, ${ }^{3}$ it was found that the children of Terenas Indians, from the villages of Limão

1. Full-professor, Universidade Federal de São Paulo - Escola Paulista de Medicina (UNIFESP/EPM), São Paulo, SP, Brazil.

2. PhD. Professor, Department of Pediatrics, Universidade Federal do Mato Grosso do Sul (UFMS), Campo Grande, MS.

3. Professor. Chancellor of Universidade Federal de São Paulo - Escola Paulista de Medicina (UNIFESP/EPM), São Paulo, SP, Brazil.

Manuscript received Jan 11 2005, accepted for publication May 112005.

Suggested citation: Morais MB, Alves GM, Fagundes-Neto U. Nutritional status of Terena indian children from Mato Grosso do Sul, Brazil: follow up of weight and height and current prevalence of anemia. J Pediatr (Rio J). 2005;81:383-9.
Verde and Córrego Seco, located in the district of Aquidauana, exhibited a pattern of weight and stature comparable with other groups indigenous to Brazil, characterized by a deficit in height for age and appropriate weight for height. ${ }^{4-10}$

A study undertaken of the children of Alto Xingu Indians found that from 1980 to 1992, a statistically significant reduction in median height for age z-score had occurred, 10 emphasizing the importance of periodic assessments of the nutritional status of indigenous groups since cultural changes over the long term could be associated with alterations to the anthropometric pattern of the child population. ${ }^{4}$

Iron deficiency anemia presents an elevated prevalence in developing countries, afflicting most often infants, preschool aged children, adolescents and women of a fertile age. ${ }^{11,12}$ During childhood, the principal causative factors of iron deficiency are an insufficient iron intake and increased demands for iron due to growth. ${ }^{11,12}$ For the city of São Paulo there is evidence demonstrating an increase in the 
prevalence of iron deficiency anemia in the child population since the $1970 \mathrm{~s},{ }^{13}$ in contrast with the prevalence of protein-energy malnutrition which reduced over the same period. ${ }^{14}$ Despite the importance of iron deficiency anemia as a nutritional problem of great significance to the health of the pediatric population, there is little information with respect of the prevalence of anemia among groups of indigenous Brazilians. 5,8

The objectives of this study were to compare the weight and stature of Terenas Indian children less than ten years old, sampled at two different times (1995 and 2002) and to verify the presence of anemia in this population in 2002 .

\section{Patients and methods}

The study was performed at the Terenas villages of Limão Verde and Córrego Seco, located in the district of Aquidauana, in Mato Grosso do Sul state. Based on fieldwork undertaken in 1995, the number of inhabitants of the villages was estimated at $1,500 .{ }^{3}$ The dwellings in the Limão Verde and Córrego Seco villages have walls made from tree trunks and clay and roofs made from leaves of the aguaje palm (Mauritia flexuosa). They do not have electricity or running water. Terenas Indians cultivate corn, beans, rice, cassava and fruit, with the small quantities that exceed their subsistence needs being sold at market in the towns of Aquidauana or Campo Grande.

This is a cross-sectional study, analyzing the child population inhabiting the Limão Verde and Córrego Seco villages at two different points in time (1995 and 2002). With the single inclusion criterion of attempting to study the largest possible number children less than ten years old. In 1995 it proved possible to include this age group in its entirety, summing 253 children (122 were male and 131 were female). In 2002, based on the same inclusion criterion, 244 children were evaluated ( 112 were male and 132 were female) which accounted for more than $90 \%$ of the children in this age group. All of the children were not studied in 2002 because of the limited time available for fieldwork, i.e. it was not possible to make a return visit to see those children who had been absent on the examination days.

In 2002, hemoglobin in thumb prick blood was assayed for 167 children. The intention had been to assay the hemoglobin of all children aged 6 months to 5 years. In the event, hemoglobin was assayed for $43(95.6 \%)$ of the 45 infants aged 6 to 24 months and for 65 (94.2\%) of the 69 children aged 24 to 60 months. The single limiting factor resulting in the non-inclusion of all children in the anemia prevalence assessment was the number of test kits available at the time the fieldwork was carried out. This was the reason that the age group from 60 to 120 months was evaluated with a sample of convenience including approximately half of the study group, specifically $59(48.9 \%)$ of the 121 children aged 60 to 120 months. The presence or absence of clinical signs or symptoms indicating anemia did not influence the choice of which children would undergo hemoglobin assay.
Measurements of weight and stature were taken according to recommendations made by Jelliffe for studies in the community. ${ }^{1}$ Weight was measured using one of two mechanical scales, one for infants and the other for larger children, both for the survey performed in 1995 and that undertaken in 2002. The children were weighed unclothed or using lightweight underclothes, particularly those in the school age and preschool age groups. Length was measured for children up to 2 years old with the child in decubitus dorsal and, from this age onwards, height was measured standing. Two anthropometers were used for this. For all stature measurements, due precautions were taken to maintain the spine and legs straight. The z-scores and percentages for the match between weight and age, weight and stature and stature and age were calculated using EpiInfo version $6.2,{ }^{15}$ based on the reference values in the NCHS (National Center for Health Statistics) table. ${ }^{16} \mathrm{~A}$ cutoff of -2 standard deviations was adopted for deficits of weight for stature, weight for age and stature for age, in accordance with World Health Organization recommendations. ${ }^{2}$

Hemoglobin concentration was determined using a portable photometer (HemoCue, Angelholm, Sweden) and a blood sample collected by thumb prick. Blood was not collected fasting.

The definition used for anemia obeys the cutoff points established in 1999 by the World Health Organization: 12 $11 \mathrm{~g} / \mathrm{dl}$ from 6 to 72 months and $11.5 \mathrm{~g} / \mathrm{dl}$ for children aged 73 to 120 months. For purposes of comparison the prevalence of anemia between 60 and 120 months was also calculated based on the $12 \mathrm{~g} / \mathrm{dl}$ cutoff point which had been recommended by the World Health Organization for this age group prior to 1999.11

The majority of the variables involved do not present standard deviation and, for this reason, the Mann-Whitney test was used to compare continuous variables for the two independent groups. Calculations were performed using Jandel Sigma Stat for Windows (SPSS Inc, Chicago, IL, USA). Categorical variables were analyzed using the chisquare test or Fisher's exact test using Epi-Info version 6.2. ${ }^{15}$ The level of statistical significance was defined as $5 \%$ (alpha error $=0.05$ ).

The project was approved by the Commission for Ethics in Research at the Universidade Federal do Mato Grosso do Sul and the Fundação Nacional do Índio do Mato Grosso do Sul. The phase undertaken in 1995 was also approved by the Ethics Commission at the Universidade Federal de São Paulo - Escola Paulista de Medicina. Informed consent in writing was obtained from the village leaders as laid out in the applicable regulations.

\section{Results}

Table 1 presents the percentages of Indian children with deficits in weight for age, weight for stature and stature for age, by study year and age group. A reduction was observed in the percentage of deficit in weight for stature, in the 60 to 120 months age range, but the difference did not reach 
statistical significance $(p=0.054)$. A reduction was also observed in the percentage of stature for age deficit among children aged 24 to 60 months, but this difference also failed to reach statistical significance $(p=0.053)$. The proportion of stature for age deficit oscillated between 5.6 and $9.9 \%$, without statistical significance $(p=0.328)$. It was only possible to perform a statistical analysis of the percentages of children with anthropometric deficits by age group and for each study phase for stature for age, as detailed in the footnote to Table 1 . The chi-square test could not be used for the weight-age and weight-stature indicators because the expected value was below 5 in at least one case. The proportion of stature for age in 1995 was found to be statistically lower between 60 and 120 months.

Taking the individual $z$-score values as continuous variables, expressed as medians and 25th and 75th percentiles (Table 2), the Mann-Whitney test revealed a statistically significant reduction in median weight for age and weight for stature deficits in the under 24 month age group, when compared with the NCHS reference values. A reduction was confirmed in weight for age and stature for age deficits in the 24 to 60 month age group. No statistically significant variation was observed in the anthropometric parameters of the 60 to 120 month age group.

As was mentioned earlier, priority was given to the hemoglobin assays of children aged 6 to 60 months, with the result that $43(95.6 \%)$ of the 45 infants aged 6 to 24 months, 65 (94.2\%) of the 69 children aged 24 to 60 months and $59(48.9 \%)$ of the 121 aged 60 to 120 months were assayed. Table 3 shows the prevalence of anemia in the study population. Anemia prevalence was elevated in all three age groups, being greatest among the infants, as was demonstrated by the statistical study. Taking the cutoff point to be $12 \mathrm{~g} / \mathrm{dl}$ of hemoglobin 60 to 120 months, the prevalence of anemia was $57.6 \%$.

Table 4 presents medians for weight for age, weight for stature and stature for age z-scores according to the presence or absence of anemia, for the three age groups. The only statistical difference identified by the MannWhitney test was between anemic children and children with normal hemoglobin, aged 24 to 60 months, with the anemic children having lower stature for age z-scores.

\section{Discussion}

The weight and stature measurements of the indigenous Terenas children obtained in 2002 confirm the nutritional profile observed in 1995,3 i.e. a predominance of stature for age deficit over weight for stature deficit. The comparison of anthropometric data from 1995 with those from 2002 revealed an increase in the weight of infants, characterized by a statistically significant increase in the median weight for age and weight for stature z-scores (Table 2). This change was not associated with a statistical reduction in the proportion of infants with deficits (z-score $<-2$ standard deviations) in weight for age and weight for

Table 1 - Percentages of Indian children with deficits in weight for age, weight for stature and stature for age, according to age range, in 1995 and 2002

\begin{tabular}{|c|c|c|c|c|c|c|c|}
\hline & \multicolumn{3}{|c|}{1995} & \multicolumn{3}{|c|}{2002} & \multirow[b]{2}{*}{$\mathbf{p}$} \\
\hline & $\mathbf{n}$ & Deficit & $\%$ & $\mathbf{n}$ & Deficit & $\%$ & \\
\hline \multicolumn{8}{|l|}{ Weight-age } \\
\hline$<24 \mathrm{~m}$ & 61 & 2 & 3.3 & 54 & 2 & 3.7 & 1.000 \\
\hline $24-60 m$ & 84 & 6 & 7.1 & 69 & 2 & 2.9 & 0.295 \\
\hline $60-120 m$ & 108 & 2 & 1.9 & 121 & 3 & 2.5 & 1.000 \\
\hline Total & 253 & 10 & 4.0 & 244 & 7 & 2.9 & 0.676 \\
\hline \multicolumn{8}{|c|}{ Weight-stature } \\
\hline$<24 \mathrm{~m}$ & 61 & 1 & 1.6 & 54 & 0 & 0.0 & 1.000 \\
\hline $24-60 m$ & 84 & 2 & 2.4 & 69 & 1 & 1.5 & 1.000 \\
\hline $60-120 m$ & 108 & 6 & 4.8 & 121 & 1 & 0.8 & 0.054 \\
\hline Total & 253 & 9 & 3.6 & 244 & 2 & 0.8 & 0.077 \\
\hline \multicolumn{8}{|l|}{ Stature-age } \\
\hline$<24 \mathrm{~m}$ & 61 & 14 & 23.0 & 54 & 9 & 16.7 & 0.543 \\
\hline $24-60 m$ & 84 & 18 & 21.4 & 69 & 6 & 8.7 & 0.053 \\
\hline $60-120 m$ & 108 & 6 & 5.6 & 121 & 12 & 9.9 & 0.328 \\
\hline Total & 253 & 38 & 15.0 & 244 & 27 & 11.1 & 0.240 \\
\hline
\end{tabular}

Statistical comparison of deficits proportions, according to age range in 1995 and 2002:

- Weight-age and weight-stature: it was not possible to perform statistical analysis, both in 1995 and 2002 ;

- Stature-age: 1995 - chi-square: $p=0.001$ (chi-square partitioning: $60-\mid 120 \mathrm{~m}<$ [<24 m and $60-\mid 120$ m]); 2002 - chi-square: $p=0.320$. 
Table 2 - Median and 25th and 75th percentiles (in parenthesis) of z-score values of weight for age, weight for stature, and age for stature in Indian children, according to age ranges, in 1995 and 2002

\begin{tabular}{|c|c|c|c|}
\hline $\begin{array}{l}\text { Age range } \\
\text { and z-score }\end{array}$ & \multicolumn{2}{|c|}{ Year } & $\mathbf{p}$ \\
\hline \multicolumn{4}{|l|}{$<24$ months } \\
\hline Number & 61 & 54 & \\
\hline \multirow[t]{2}{*}{ Weight-age } & -0.780 & -0.220 & \\
\hline & $(-1.375$ e -0.040$)$ & $(-0.890$ e +0.860$)$ & 0.003 \\
\hline \multirow[t]{2}{*}{ Weight-stature } & -0.030 & +0.715 & \\
\hline & $(-0.505 e+1.058)$ & $(0.000 \mathrm{e}+1.420)$ & 0.014 \\
\hline \multirow[t]{2}{*}{ Stature-age } & -1.070 & -1.050 & \\
\hline & $(-1.848$ e -0.623$)$ & $(-1.760$ e -0.170$)$ & 0.426 \\
\hline \multicolumn{4}{|l|}{$24-60 \mathrm{~m}$} \\
\hline Number & 84 & 69 & \\
\hline \multirow[t]{2}{*}{ Weight-age (z) } & -0.390 & -0.130 & \\
\hline & $(-1.165$ e +0.160$)$ & $(-0.710$ e +0.292$)$ & 0.046 \\
\hline \multirow[t]{2}{*}{ Weight-stature (z) } & +0.350 & +0.420 & \\
\hline & $(-0.590$ e +0.975$)$ & $(+0.085$ e +0.972$)$ & 0.169 \\
\hline \multirow[t]{2}{*}{ Stature-age (z) } & -1.005 & -0.720 & \\
\hline & $(-1.630$ e -0.420$)$ & $(-1.392 \mathrm{e}-0.163)$ & 0.042 \\
\hline \multicolumn{4}{|l|}{$60-120 \mathrm{~m}$} \\
\hline Number & 108 & 121 & \\
\hline \multirow[t]{2}{*}{ Weight-age (z) } & -0.095 & -0.010 & \\
\hline & $(-0.815$ e +0.410$)$ & $(-0.683 e+0.405)$ & 0.595 \\
\hline \multirow[t]{2}{*}{ Weight-stature (z) } & +0.500 & +0.410 & \\
\hline & $(-0.425 e+1.455)$ & $(+0.018$ e +0.900$)$ & 0.660 \\
\hline \multirow[t]{2}{*}{ Stature-age (z) } & -0.605 & -0.620 & \\
\hline & $(-1.225$ e -0.180$)$ & $(-1.185 \mathrm{e}+0.055)$ & 0.385 \\
\hline
\end{tabular}

stature (Table 1). There was also a statistically significant increase in the median weight for age and stature for age z-scores for the children aged 24 to 60 months, over the period from 1995 to 2002 (Table 2). The results of the present study, therefore, do not provide evidence of a deterioration in the nutritional condition of the children of

Table 3 - Prevalence of anemia anemia in Indian children ranging between 6 and 120 months, in 2002

\begin{tabular}{lccc}
\hline & $\begin{array}{c}\text { Children } \\
\text { assessed }\end{array}$ & Anemia * & \% Anemia \\
\hline $6-\mid 24 \mathrm{~m}$ & 43 & 37 & 86,1 \\
$24-\mid 60 \mathrm{~m}$ & 65 & 33 & 50,8 \\
$60-\mid 120 \mathrm{~m}$ & 59 & 24 & 40,7 \\
Total & 167 & 104 & 62,3 \\
\hline
\end{tabular}

* Anemia: hemoglobin $<11 \mathrm{~g} / \mathrm{dl}$ in children ranging from 6 to 60 months and hemoglobin $<11.5 \mathrm{~g} / \mathrm{dl}$ in children ranging from 60 to 120 months. Statistical analysis: chi-square test: $p<0.001$.

Chi-square partitioning: $6-\mid 24>(24-\mid 60$ e $60-\mid 120)$. the Terenas Indians, since during the study period indicators of improvements in nutritional status have been observed, especially in weight, from 0 to 60 months of life, and stature, from 24 to 60 months. These results, demonstrating an increase in the weight of the children of the Terenas Indians, could, from a speculative perspective, be an indication of the initial phase of a nutritional transition process, along the lines of what is happening in the Brazilian population, ${ }^{14}$ and which should also be a cause for concern in indigenous populations. ${ }^{17}$ In synthesis, the results of the present study demonstrate a reduction in nutritional deficits, especially when analyzed using the medians of the z-scores.

Concerning stature, as has been pointed out earlier, ${ }^{3}$ there is no easy explanation for the greater frequency of stature deficit that was observed for the under 60 months age group in 1995, compared with the 60 to 120 month age group. In 2002, a reduction was observed in the proportion of stature for age deficit in this age group, with a statistically significant tendency for 24 to 60 months (Table 1 ). Thus, the results of the present study, revealing a stature for age deficit in 15 and $11.1 \%$ of the children 
Table 4 - Medians and 25th and 75th percentiles (in parenthesis) for weight for age, weight for stature and stature for age z-scores according to the presence or absence of anemia and age range, in 2002

\begin{tabular}{|c|c|c|c|}
\hline $\begin{array}{l}\text { Age range } \\
\text { and } z \text {-score }\end{array}$ & Yes & mia & $\mathbf{p}$ \\
\hline \multicolumn{4}{|l|}{$6-124 m$} \\
\hline Number & 37 & 6 & \\
\hline Weight-age (z) & $-0.310(-0.940 ;+0.873)$ & $-0.830(-1.000 ;+0.390)$ & 0.220 \\
\hline Weight-stature (z) & $+0.730(+0.075 ;+1.583)$ & $+0.045(-0.570 ;+0.690)$ & 0.309 \\
\hline Stature-age (z) & $-1.200(-1.885 ;-0.283)$ & $-1.440(-1.760 ;-0.790)$ & 1.00 \\
\hline \multicolumn{4}{|l|}{$24-60 \mathrm{~m}$} \\
\hline Number & 33 & 32 & \\
\hline Weight-age (z) & $-0.360(-0.787 ;+0.100)$ & $+0.080(-0.35 ;+0.490)$ & 0.105 \\
\hline Weight-stature (z) & $+0.340(+0.035 ;+0.910)$ & $+0.435(-0.025 ;+1.230)$ & 0.875 \\
\hline Stature-age (z) & $-1.260(-1.773 ;-0.420)$ & $-0.390(-1.145 ;+0.080)$ & 0.008 \\
\hline \multicolumn{4}{|l|}{$60-120 \mathrm{~m}$} \\
\hline Number & 24 & 35 & \\
\hline Weight-age (z) & $-0.555(-1.265 ;+0.010)$ & $+0.160(-0.738 ;+0.308)$ & 0.167 \\
\hline Weight-stature (z) & $+0.270(-0.278 ;+0.830)$ & $+0.260(-0.315 ;+0.778)$ & 0.902 \\
\hline Stature-age (z) & $-1.155(-1.595 ;-0.010)$ & $-0.570(-0.863 ;-0.065)$ & 0.163 \\
\hline
\end{tabular}

studied (aged 0 to 120 months) in 1995 and 2002, respectively, are similar to those observed in children living in the Xingu Indigenous Park $(19.8 \%$ in Alto Xingu tribes $^{6}$ and $12 \%$ in Panará Indians). ${ }^{8}$ In contrast, other indigenous groups have exhibited much greater proportions of stature for age for the same age group, for example, the Tupi-Mondê (55.4\%) in Rondonia and Mato Grosso states $^{4}$ and the Surui from Rondonia ${ }^{17}$ and the Ikpeng ( $37.7 \%$ ) from the Alto Xingu. ${ }^{18}$ Taking just the age group from 0 to 60 months, the values found in the present study (22.1\% in 1995 and $12.2 \%$ in 2002) are comparable to those observed, in 1990, in another Terena village in do Mato Grosso do Sul state $(16 \%)^{9}$ and in the Xavantes of Mato Grosso (11.3\%). ${ }^{7}$ Studies undertaken in several different regions worldwide, including Brazil, 19,20 have revealed a secular tendency towards increased stature. An absence of this positive secular variation in stature can be interpreted in one of two ways: 1) As a nutritional deterioration in the socio-economic and cultural conditions of a population group, resulting in environmental conditions that are inadequate for growth; or 2) the population groups is living in ideal conditions and in the past has already fully expressed its genetic growth potential. ${ }^{21}$ The first of these two possibilities is more probable in the case of the Terena community being studied, although consideration must also be given to the possibility that the seven-year interval between 1995 and 2002 may not be long enough to detect a secular stature variation. A study of the children of Alto Xingu Indians did not find evidence of increased stature over a twelve-year period from 1980 to 1992.10 These data underscore the importance of periodical monitoring of the nutritional status of several different population groups, including indigenous groups who are going through a process of changing their cultural characteristics, lifestyle and feeding patterns.

These data also indicate that different indigenous groups exhibit distinct growth patterns, probably as a result of the interaction of heterogeneous genetic and environmental factors. This being so, the interpretation of anthropometric data from different indigenous groups should be performed with extreme caution, whether when comparing with the $\mathrm{NCHS}$ values or whether making direct comparisons between different indigenous groups.

The prevalence of anemia among the Terenas children was $86.1 \%$ from 6 to 24 months, $50.8 \%$ from 24 to 60 months and $40.7 \%$ for 60 to 120 month old children. In 1975, when the Panará arrived at the Xingu Indigenous Park, $68 \%$ of their children less than 10 years old presented with hemoglobin below $11 \mathrm{~g} / \mathrm{dl}$, whereas, in 1998 this figure had dropped to $42 \% .{ }^{8}$ In 1991, a $70 \%$ prevalence of anemia was observed among Suruí children under 5 years of age. 5 Based on the scarce data that are available, it is possible to state that anemia is a significant health problem among indigenous children in Brazil, in common with what has been observed of our country's child population who live in urban or rural areas, especially from 6 to 24 months of age. ${ }^{22}$ There is also little information on the prevalence of anemia in schoolchildren and for this age group care must be taken with which cutoff point has been adopted. This is dealt with 
well by a study ${ }^{23}$ performed in Alagoas, in which both of the cutoff points recommended by the World Health Organization were used: the $12 \mathrm{~g} / \mathrm{dl}$ that was traditionally recommended ${ }^{11}$ and the less rigorous value of $11.5 \mathrm{~g} / \mathrm{dl}$ that has been adopted since 1999.12 Taking first the $11.5 \mathrm{~g} / \mathrm{dl}$ cutoff, the prevalence of anemia among the children of the Terenas Indians aged 60 to 120 months was $40.7 \%$, which is above the level found among schoolchildren aged 6 to 12 years from low income families in the state of Paraná $(25.7 \%)^{24}$ and around three to four times greater than the 9.9 and $13 \%$ that were found for schoolchildren in state-run schools in the cities of Rio de Janeiro and Maceió, respectively. ${ }^{23}$ If the $12 \mathrm{~g} / \mathrm{dl}$ cutoff is used, $57.6 \%$ of the Terenas children would be diagnosed as anemic. This value is comparable to that observed among schoolchildren at state schools in Osasco (51\%) and greater than that observed in Aracaju (26.7\%). ${ }^{25}$

In two articles published Brazil anemia and stature deficit were treated as categorical variables and no association was identified. ${ }^{23,26}$ In our study, taking the $z$-scores as continuous variables, it was possible to identify a lower median stature for age z-score among children suffering from anemia aged 24 to 60 months. Weight and stature can become compromised when there is an iron deficiency, as demonstrated by studies performed in other countries. ${ }^{27}$ A study performed in Brazil demonstrated weight gain in anemic children after 8 weeks of oral iron therapy. ${ }^{28}$ Despite this link between iron deficiency and weight deficit, it is unlikely that the high percentages of stature for age deficits observed among the children of Brazilian Indians has a cause-effect relationship with a deficiency of this mineral. Studies are needed that are specifically designed to investigate this issue.

Concerning the etiology of anemia, it is believed that, in the community the great majority of anemia cases are the result of iron deficiency. ${ }^{11,12}$ Iron deficiency itself, is basically dependent on insufficient ingestion and assimilation of iron from the diet. ${ }^{11,12}$ This feature was evaluated with Terena children living in the Córrego do Meio village in Mato Grosso do Sul. ${ }^{9}$ They observed that, ${ }^{9}$ based on a 24 -hour dietary recall, the mean estimated percentage of recommended iron intake was $14.1 \%$ for 6 to 11 months of age, $33 \%$ for 12 to 24 months and $60.4 \%$ from 24 to 59 months, confirming insufficient iron consumption. In ancylostomiasis there is also the possibility of blood loss caused by intestinal parasites. Tests for parasites performed in the nineties found Giardia lamblia in 30.3\%, Hymenolepsis nana in $10.6 \%$, Necator americanus in 3.3\%, Strongyloides stercoralis in $3.3 \%$ and Ascaris lumbricoides in $1.6 \%$ of the children in the villages evaluated. ${ }^{3}$ The occurrence of ancylostomiasis in $3.3 \%$ of the children, cannot therefore explain the high levels of anemia found among the Terenas children. Furthermore, it is unlikely that giardiasis, unassociated with chronic diarrhea, can cause poor intestinal iron intake. ${ }^{29}$ In other words, everything indicates that the cause of the anemia observed in the Terenas villages studied is iron deficiency.

Concluding, between 1995 and 2002 an improvement was observed in the nutritional indicators weight and stature, together with the maintenance of stature for age deficit as the principal nutritional problem among the children of the Terenas Indians, in common with other indigenous groups in Latin America. The prevalence of anemia was extremely elevated, indicating the need for measures to combat it with alacrity.

\section{Acknowledgements}

The Terenas responsible for the clinics at the Limão Verde and Córrego Seco villages.

\section{References}

1. Jelliffe DB. Evaluatión del estado nutricional de la comunidad. Ginebra: Organização Mundial de la Salut, 1968.

2. World Health Organization Expert Committee. Physical status: the use and interpretation of anthropometry. WHO Technical Report Series, 854. Geneva: World Health Organization, 1995.

3. Alves GM, Morais MB, Fagundes-Neto U. 2002. Estado nutricional e teste do hidrogênio no ar expirado com lactose e lactulose em crianças indígenas Terenas. J Pediatr (Rio J). 2002;78:113-9.

4. Santos RV, Coimbra Jr CE. Socioeconomic transition and physical growth of Tupi-Mondê Amerindian children of the Aripuanã Park, Brazilian Amazon. Hum Biol. 1991;63:795-819.

5. Coimbra Jr CE, Santos RV. Avaliação do estado nutricional num contexto de mudança sócio-econômica: o grupo indígena Suruí do Estado de Rondônia, Brasil. Cad Saude Publica. 1991;7: 538-62.

6. Mattos AP, Morais MB, Rodrigues D, Baruzzi RG. Nutritional status and dietary habits of Indian children from Alto Xingu (Central Brazil) according to age. J Am Coll Nutr. 1999;18:88-94.

7. Gugelmin SA, Santos RV, Leite MS. Crescimento físico de crianças indígenas xavantes de 5 a 10 anos de idade em Mato Grosso. J Pediatr (Rio J). 2001;77:17-22.

8. Baruzzi RG, Barros VL, Rodrigues $D$, Souza $A L$, Pagliaro $H$. Saúde e doença em índios Panará (Kreen-Akarôre) após vinte e cinco anos de contato com o nosso mundo, com ênfase na ocorrência de tuberculose (Brasil Central). Cad Saude Publica. 2001;17:407-12.

9. Ribas DL, Sganzerla A, Zorzatto JR, Phillipi ST. Nutrição e saúde infantil em uma comunidade indígena Terena, Mato Grosso do Sul, Brasil. Cad Saude Publica. 2001;17:323-31.

10. Morais MB, Fagundes-Neto U, Mattos AP, Baruzzi RG. Estado nutricional de crianças índias do Alto Xingu em 1980 e 1992 e evolução pondero-estatural entre o primeiro e o quarto anos de vida. Cad Saude Publica. 2003;19:543-50.

11. DeMayer EM. Preventing and controlling iron deficiency anaemia through primary health care. Geneva: World Health Organization; 1989.

12. UNICEF (United Nations Children's Fund)/UNU (United Nations University)/WHO (World Health Organization)/MI (Micronutrient Initiative). Preventing Iron Deficiency in Women and Children. Technical Workshop. Boston: International Nutrition Foundation, 1999.

13. Monteiro CA, Szarfarc SC, Mondini L. Tendência secular da anemia na infância na cidade de São Paulo (1984-1996). Rev Saude Publica. 2000;34:62-72.

14. Monteiro CA, Conde WL. Tendência secular da desnutrição e da obesidade na infância na cidade de São Paulo (1974-1996). Rev Saude Publica. 2000;34:52-61.

15. Dean AG. Epi-Info version 5.1: a word processor, database and statistics program for epidemiology on micro-computers. Georgia: Center for Disease Control; 1990.

16. World Health Organization. Measuring change in nutritional status: guidelines for assessing the nutritional impact of supplementary feeding programs for vulnerable groups. Geneva: World Health Organization; 1983.

17. Santos RV, Coimbra Jr CE. Cenários e tendências da saúde e da epidemiologia dos povos indígenas no Brasil. In: Coimbra Jr CE. Epidemiologia e saúde dos povos indígenas no Brasil. Rio de Janeiro: Fiocruz/Abrasco; 2003. p. 13-47.

18. Fagundes U, Kopelman BI, Oliva CA, Baruzzi RG, FagundesNeto U. Avaliação do estado nutricional e da composição corporal de crianças índias do Alto Xingu e da etnia Ikpeng. J Pediatr (Rio J). 2004;80:483-9. 
19. Monteiro CA, Benicio MH, Gouveia NC. Secular growth trends in Brazil over three decades. Ann Hum Biol. 1994;21:381-90.

20. Kac G. Tendência secular em estatura em recrutas da Marinha do Brasil nascidos entre 1940 e 1965. Cad Saude Publica. 1998; 14:565-73.

21. Kac G. Tendência secular em estatura: uma revisão da literatura. Cad Saúde Publica. 1999;15:451-61.

22. Osório MM. Fatores determinantes da anemia em crianças. J Pediatr (Rio J). 2002;78:269-78.

23. Santos CD, Santos LM, Figueiroa JN, Marroquim PM, Oliveira MA. Anemia em escolares da primeira série do ensino fundamental da rede pública de Maceió, Alagoas, Brasil. Cad Saude Publica. 2002; 18:1757-63.

24. Sichieri R, Mathias T, Moura AS. Stunting, high weight-forheight, anemia e dietary intake among brazilian students from a rural community. Nutr Res. 1996;16:201-9.

25. Tsuyuoka R, Bailey JW, Guimarães AM, Gurgel RQ, Cuevas LE. Anemia and intestinal parasitic infections in primary school students in Aracaju, Sergipe, Brazil. Cad Saude Publica. $1999 ; 15: 413-21$.
26. Almeida AP, Zandonade $E$, Abrantes MM, Lamounier JA. Deficiência de ferro e anemia em crianças de Vitória, ES. Pediatria (São Paulo). 2004;26:140-50.

27. Aukett MA, Parks YA, Scott PH, Wharton BA. Treatment with iron increases weight gain and psychomotor development. Arch Dis Child. 1986;61:849-57.

28. Morais MB, Ferrari AA, Fisberg M. Effect of oral iron therapy on physical growth. Rev Paul Med. 1993;111:439-44.

29. Morais MB, Suzuki HU, Corral JN, Machado NL, Fagundes-Neto $\mathrm{U}$. Asymptomatic giardiasis does not affect iron absorption in children with iron deficiency anemia. J Am Coll Nutr. 1996;15: 434-8.

Correspondence:

Mauro Batista Morais

Rua Pedro de Toledo, 441

CEP 04039-031, São Paulo, SP, Brazil

E-mail: mbmorais@osite.com.br 